\title{
Does the long-term success of REDD+ also depend on biodiversity?
}

\author{
Amy Hinsley, Abigail Entwistle and Dorothea V. Pio
}

\begin{abstract}
Originally proposed in 2005 as a way to use financial incentives to tackle global climate change, Reducing Emissions from Deforestation and forest Degradation (REDD) has evolved to include conservation, sustainable management of forests and enhancement of forest carbon stocks, in what is now known as REDD+. Biodiversity protection is still viewed principally as a cobenefit of the REDD+ process, with conservation of forest tree cover and carbon stocks providing the main measure of success. However, focusing solely on tree cover and carbon stocks does not always protect other species, which may be threatened by other factors, most notably hunting. We present evidence from the literature that loss of biodiversity can affect forest composition, tree survival and forest resilience and may in some cases ultimately lead to a reduction in carbon storage. We argue that REDD+ projects should specifically mitigate for threats to biodiversity if they are to maximize carbon storage potential in the long term.
\end{abstract}

Keywords Biodiversity, carbon, climate change, defaunation, hunting, REDD+, seed dispersal, tropical forest

\section{Introduction}

Deducing Emissions from Deforestation and forest Regradation (REDD) is an increasing part of the international community's efforts to tackle global climate change, and also a key mechanism to create an incentive for forest protection (Clements, 2010). The inclusion of issues around conservation, sustainable development and forest restoration alongside carbon storage, led to its rebranding as REDD+ (Parker et al., 2009; Venter \& Koh, 2012).

REDD+ addresses an important cause of carbon emissions: the world's forests hold an estimated 289 gigatonnes of carbon but 13 million ha per year (0.325\% of total) is lost or degraded (FAO, 2010). The loss and

Amy Hinsley* (Corresponding author), Abigail Entwistle and DoROTHEA V. PIO Fauna \& Flora International, Cambridge, UK. E-mail ah371@kent.ac.uk

*Current address: Durrell Institute of Conservation and Ecology, School of Anthropology and Conservation, Marlowe Building, University of Kent, Canterbury, CT2 7NZ, UK

Received 25 November 2013. Revision requested 26 February 2014.

Accepted 3 June 2014. First published online 10 October 2014. degradation of tropical forests in particular is happening rapidly and is responsible for an estimated $12 \%$ of anthropogenic carbon emissions (van der Werf et al., 2009). Even existing protected areas, which contain $18.5 \%$ of humid tropical forest carbon, are not immune to forest loss: an estimated 1.75 million ha of forest in protected areas were lost between 2000 and 2005 (Scharlemann et al., 2010). Currently REDD+ primarily uses bilateral and multilateral agreements as well as the global voluntary carbon market, valued at USD 379 million in 2013, to ensure that the incentive for forest protection is greater than that for destruction (Parker et al., 2009; Peters-Stanley et al., 2013). Successful REDD+ development and implementation requires a set of important prerequisites to be in place, such as clear and secure tenure rights to land, forests and carbon, strong local and national level forest governance, free, prior and informed consent of communities, and the political will to forego some of the opportunity costs from short-term and purely extractive land-uses in the knowledge that not all ecosystem services provided by healthy, functioning carbon-rich forests are financially quantifiable (Angelsen et al., 2012). In addition, a sufficiently strong demand for the purchase of emission reductions in national and international markets is essential if project developers, investors, forest country governments and communities are to continue contributing resources, time and effort into developing REDD+ activities (GCP, IPAM, FFI, UNEP FI \& UNORCID, 2014).

\section{REDD+ and biodiversity conservation}

REDD+ protects forests primarily for their carbon value (UNFCCC, 2008 p.3) using internationally accepted definitions of 'forest' and 'deforestation' that are based on percentage tree cover (Schoene et al., 2007; Sasaki \& Putz, 2009; van der Werf, 2009). Maintaining tree cover in carbon-rich forests will have strong positive effects on biodiversity by preventing habitat loss. There is a congruence of areas rich in carbon and biodiversity on a global scale (Strassburg et al., 2010; Cavanaugh et al., 2014), and funds from REDD+ can also flow to existing forest reserves and protected areas where lack of finance restricts forest protection (Burgess et al., 2010; Scharlemann et al., 2010). However, the overlap between carbon and biodiversity may not always be apparent at finer scales (Paoli et al., 2010) and 
in cases where it is not, REDD+ implementation may have more modest benefits for biodiversity conservation.

Without including conservation as a core objective there is no guarantee that biodiversity within a seemingly intact forest will persist (Schoene et al., 2007). Phelps et al. (2012) suggest that stronger evidence for the links between biodiversity and carbon storage is needed before it can be considered by the international community. Here we explore the available evidence to determine whether by overlooking the integral role of biodiversity in maintaining healthy forest ecosystems, we could be compromising longterm carbon storage.

\section{Biodiversity loss and its implications}

Tropical forests are complex ecosystems, underpinned by small-scale processes and species interactions that, if altered, can often have much wider effects on the diversity and functioning of the forest as a whole. Individual or groups of species may play important roles in pollination, seed dispersal or nutrient cycling and their loss can result in decreased tree recruitment (Forget \& Jansen, 2007; Wang et al., 2007; Brodie et al., 2009; Holbrook \& Loiselle, 2009) and changing forest species composition (Wright et al., 2007). Managing forests solely for carbon storage does not automatically take into account the complex interactions and interdependence of plant and animal organisms living within them (Bunker et al., 2005).

REDD+ protects a forest from clear felling and fragmentation and should prevent destructive forest fires (but see Aragão \& Shimabukuro, 2011; Barlow et al., 2012). However, it is possible for high value trees of one species to be selectively removed or for other threats that do not affect tree cover in the short term to be overlooked. The concept of the empty forest (Redford, 1992) is now well recognized; preventing the removal of trees is not always enough to protect other species within a forest. For example, forest patches set aside from clear felling, with no protection, lose more faunal species than strictly protected areas nearby (Canale et al., 2012).

\section{How hunting affects forest carbon stocks}

After habitat loss the greatest threat to mammals and birds in tropical forests is hunting (Wilkie et al., 2011). Hunting pressure for both commercial and subsistence use are increasing in many areas as a result of increasing human populations, greater demand for wild meat, and new technologies improving the global reach of wildlife trade networks (Harrison, 2011; Wilkie et al., 2011).

There is evidence of a link between defaunation as a result of hunting and short-term changes in forest diversity and species composition (e.g. Nñnez-Iturri \& Howe, 2007;
Wright et al., 2007; Vanthomme et al., 2010; Kurten, 2013), which has been cited as a possible cause for decreased carbon storage (Brodie \& Gibbs, 2009; Jansen et al., 2010). In particular, the loss of seed dispersers is thought to be an important cause of long-term changes in forest composition (Forget \& Jansen, 2007; Wang et al., 2007; Brodie et al., 2009; Holbrook \& Loiselle, 2009).

Hunting for meat often selectively targets larger-bodied species (Redford, 1992; Peres \& Palacios, 2007; Wilkie et al., 2011; Vidal et al., 2013), and subsistence hunting has been shown to target important tree seed dispersers including primates, birds, ungulates, scatter-hoarding rodents and frugivorous fish (Forget \& Jansen, 2007; Wang et al., 2007; Terborgh et al., 2008; Holbrook \& Loiselle, 2009; Anderson et al., 2011).

The effects of hunting on different tree species and forests will vary depending on the relative importance of hunted vertebrates as dispersers. An estimated $50-70 \%$ of tropical forest trees are dispersed by vertebrates (Howe \& Smallwood, 1982), with recent studies from individual forests estimating this to be 70-90\% (Maisels et al., 2001; Wright et al., 2007; Brodie et al., 2009; Poulsen et al., 2013). Some tree species may have important or even obligate relationships with vertebrate seed dispersers or pollinators (e.g. elephants as obligate seed dispersers of African forest trees, Campos-Arceiz \& Blake, 2011; and tapirs as the most efficient dispersers for the tree Maximiliana maripa in Brazil, Fragoso et al., 2003), and populations of such trees may be affected if hunting removes these species from their ecosystems.

Most seed disperser relationships are, however, nonobligate (Campos-Arceiz \& Blake, 2011). When vertebrates are removed by hunting, other vertebrates may functionally replace them (Elmqvist et al., 2003; Muller-Landau, 2007). Other forest studies show limited functional replacement when large species are lost (Vanthomme et al., 2010) and smaller-bodied seed dispersers may show reduced efficiency (Peres \& Palacios, 2007; Holbrook \& Loiselle, 2009); they may only carry seeds over much shorter distances, are not capable of dispersing larger seeds or may only disperse seeds of a small number of tree species (Peres \& Palacios, 2007; Holbrook \& Loiselle, 2009; Campos-Arceiz et al., 2012).

Hunting-induced species declines are likely to lead to a decrease in the recruitment of large trees as larger-bodied dispersers are lost, although this impact may in theory be offset by a decline in large seed predators (Muller-Landau, 2007; Wright et al., 2007). A decline in the dispersal of large tree seeds has been linked to a shift within a forest towards the dominance of wind-dispersed plants such as lianas, which are unlikely to be affected by hunting pressure (Wright et al., 2007). Whether a result of hunting or a combination of factors, there is evidence of increasing dominance of lianas in tropical forests (reviewed by Schnitzer \& Bongers, 2011). 
In western Amazonia liana dominance increased by up to $4.6 \%$ per year during 1980-2000, accompanied by an increase in total basal area and density of lianas (Philips et al., 2002). Lianas grow quickly and are able to outcompete slower growing trees for light, water and soil nutrients (Philips et al., 2002; Wright et al., 2007), but their thin stems and low wood density mean that they sequester and store relatively little carbon compared to the trees they replace (van der Heijden \& Philips, 2009). In addition, lianas may infest certain species preferentially, causing a shift in species composition to faster growing trees, which often store less carbon in the long term (van der Heijden \& Philips, 2009). This may result in a seemingly healthy forest having a greatly reduced capacity for carbon storage: one model predicts a decrease of up to $34 \%$ in the carbon storage capacity of a tropical forest in Panama (total carbon stock) following extinctions and subsequent liana infestation (Bunker et al., 2005). Higher liana density has also been linked to an increase in tree seed predation, as lianas provide a means of access for rodents and other small mammals from the forest floor to the canopy (Kilgore et al., 2010).

\section{Other potential threats to carbon stocks}

Invasions by exotic plants and animals could potentially affect carbon stocks but the evidence available for tropical ecosystems is still insufficient to be conclusive (Peltzer et al., 2010). Studies focusing on temperate forests have found that invasive species can reduce carbon storage and sequestration by increasing decomposition rates or removing native trees, dispersers or pollinators through direct predation (Roubik, 1978; Peltzer et al., 2010). Similarly, dieback of trees in temperate ecosystems because of introduced pathogens is well documented (Thompson et al., 2009). The few studies that exist for tropical ecosystems suggest significant variability in outcomes, even on a local scale. For example, invasive trees in Hawaii were found to reduce the above ground biomass of lowland rainforests but increase it in a nearby highland forest (Asner et al., 2009).

Biodiversity should provide a certain level of 'biological insurance' that strengthens the stability and resilience of a tropical forest, with diversity within functional groups being especially important (Bunker et al., 2005; Thompson et al., 2009; Miles et al., 2010). Thus a loss of biodiversity may increase the risks to forests from other threats such as climate change (Thompson et al., 2009).

Under projected climate change scenarios, tropical forests may experience more frequent disturbances, such as fires, disease outbreaks and invasions of non-native species. If a REDD+ project is to continue to be effective in the long term, the forest it protects must survive these disturbances without extensive tree mortality or long-term degradation (Miles et al., 2010). Although there is still a lack

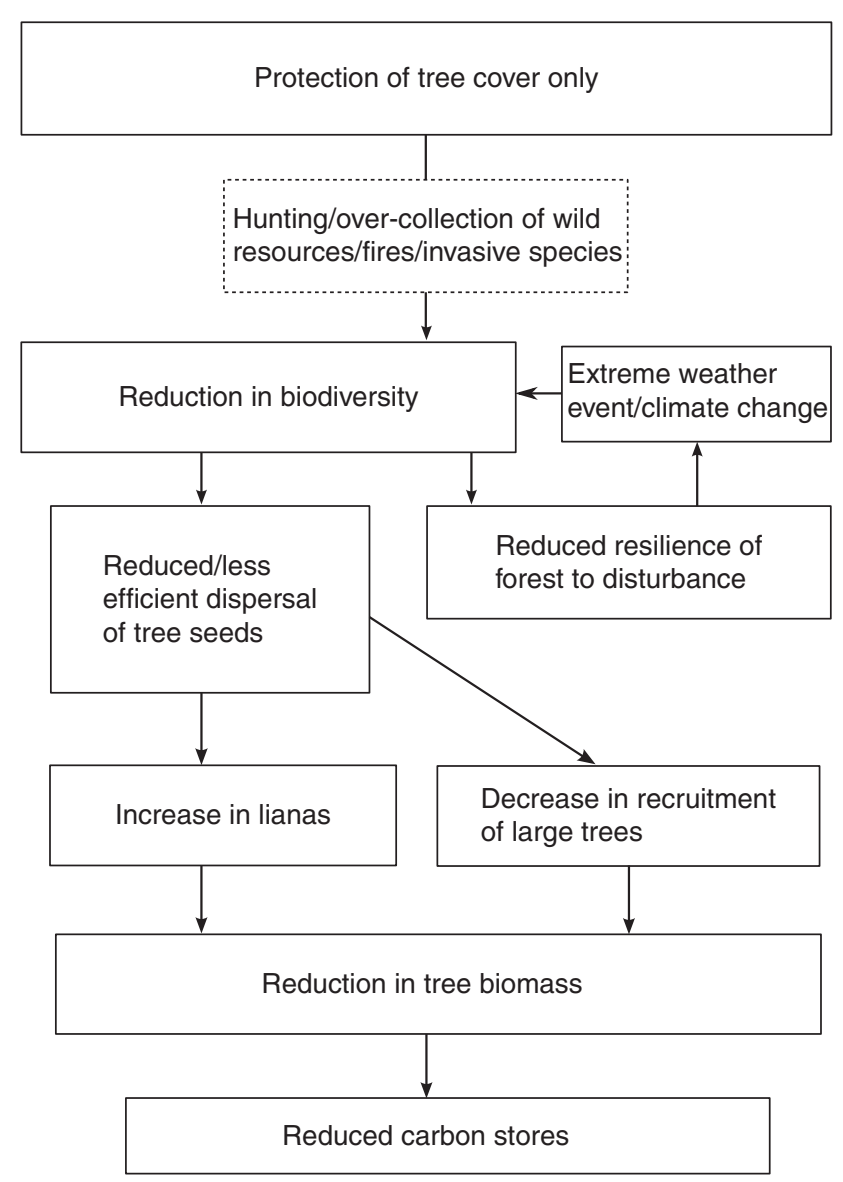

FIG. 1 The interrelationships between biodiversity and carbon sequestration and storage in tropical forests.

of direct evidence for this in tropical forests, Miles et al. (2010) note that, as research in other ecosystems has overwhelmingly demonstrated a positive correlation between biodiversity and resilience, a precautionary approach should be adopted, extending this likely relationship to tropical forests.

\section{Discussion}

The interrelationships between biodiversity and carbon sequestration and storage in tropical forests are summarized in Fig. 1. Recent evidence suggests that REDD+ will lead to the protection of areas of high biodiversity on a global scale (Cavanaugh et al., 2014). However, on a local scale we argue that the maintenance of biodiversity in these sites should not always be assumed over the long term. Successful REDD+ implementation is mostly based on proven emission reductions from avoided deforestation and degradation monitored through percentage tree cover and carbon stocks but several threats can reduce biodiversity without changing tree cover or carbon stocks in the short term, with hunting being the most widespread and best understood (Wilkie et al., 2011). Invasive species, selective 
logging and overexploitation of particular species may also occur, although the effects on tropical forest composition and biodiversity are under-researched, making it difficult to draw firm conclusions.

Hunting is an important problem in this context as it tends to target large-bodied species, especially those that disperse tree seeds (e.g. Forget \& Jansen, 2007; Holbrook \& Loiselle, 2009), and ultimately results in an over-representation of wind-dispersed plants such as lianas (Wright et al., 2007). Combined, the loss of large trees and the increase in lianas could lead to a decrease in carbon sequestration and storage in the long term (Bunker et al., 2005; van der Heijden \& Philips, 2009).

Further to these direct effects, biodiversity declines may further affect the efforts of REDD+ projects by making a forest less able to withstand damage or degradation caused by climate change (Thompson et al., 2009). This could effectively lead to a feedback loop in which biodiversity decline leads to further species losses, resulting in forest becoming degraded more quickly. As both the exact impacts of climate change and the resilience that biodiversity may provide are unknown in many tropical forests, a precautionary approach should be required (Miles et al., 2010).

We acknowledge that the relative importance of biodiversity conservation within REDD+ project development is increasing and welcome the recent efforts made by international standards that do not focus on biodiversity to streamline certification procedures with others that do (VCS \& CCB, 2013). We also note recent shifts of other international standards towards more explicit reference to biodiversity and the inclusion of biodiversity measures in project monitoring targets (Plan Vivo Foundation, 2013).

As the most widespread threat, hunting needs to be monitored and efforts to reduce unsustainable hunting should be a priority, especially where it targets important functional groups such as seed dispersers or pollinators. It has been argued that overly complicated and expensive biodiversity monitoring protocols may reduce the uptake of REDD+ (Phelps et al., 2012). The financial implications of including biodiversity measures in REDD+ monitoring targets are not our primary focus here and, although biodiversity monitoring does represent an additional cost, this is generally a fraction of that involved in overall project development. Ensuring that a small number of locally appropriate indicator species (preferably including largebodied seed dispersers) are selected and taking advantage of cost-effective tools appropriate for use by local community members are two ways of keeping these costs low. The financial implications, and more importantly the sustainability, of participatory biodiversity monitoring always compare favourably with conventional monitoring by professional ecologists. Ultimately, if biodiversity loss results in REDD+ projects reducing their impact in the long term, basic biodiversity monitoring may be too important to ignore.

\section{Acknowledgements}

We thank Josh Kempinski, Zoë Cullen and Matthew Linkie from Fauna \& Flora International for input to this article, and support from Esther Bertram, Georgina Magin and the Global Trees Campaign.

\section{References}

Anderson, J.T., Nuttle, T., Rojas, J.S.S., Pendergast, T.H. \& Flecker, A.S. (2011) Extremely long-distance seed dispersal by an overfished Amazonian frugivore. Proceedings of the Royal Society B: Biological Sciences, 278, 3329-3335.

Angelsen, A., Brockhaus, M., Sunderlin, W.D. \& Verchot, L. (2012) Analysing REDD+ Challenges and Choices. Center for International Forestry Research, Bogor, Indonesia.

Aragão, L.E. \& Shimabukuro, Y.E. (2011) The incidence of fire in Amazonian forests with implications for REDD. Science, 328 , 1275-1278.

Asner, G., Hughes, F., Varga, T., Knapp, D. \& KennedyBowdoin, T. (2009) Environmental and biotic controls over aboveground biomass throughout a tropical rain forest. Ecosystems, 12, 261-278.

Barlow, J., Patty, L., Gardnera, T., Ferreira, J., Aragão, L., CARMENTA, R. et al. (2012) The critical importance of considering fire in REDD+ programs. Biological Conservation, 154, 1-8.

Brodie, J.F. \& GibBs, H.K. (2009) Bushmeat hunting as climate threat. Science, 326, 364-365.

Brodie, J.F., Helmy, O.E., Brockelman, W.Y. \& Maron, J.L. (2009) Bushmeat poaching reduces the seed dispersal and population growth rate of a mammal-dispersed tree. Ecological Applications, 19, 854-863.

Bunker, D.E., DeClerck, F., Bradford, J.C., Colwell, R.K., Perfecto, I., Phillips, O.L. et al. (2005) Species loss and aboveground carbon storage in a tropical forest. Science, 310 , 1029-1031.

Burgess, N.D., Bahane, B., Clairs, T., Danielsen, F., DAlsgaARD, S., FUnder, M. et al. (2010) Getting ready for REDD+ in Tanzania: a case study of progress and challenges. Oryx, 44, 339-351.

Campos-Arceiz, A. \& Blake, S. (2011) Megagardeners of the forest-the role of elephants in seed dispersal. Acta Oecologica, 37, $542-553$.

Campos-Arceiz, A., Traeholt, C., Jaffar, R., Santamaria, L. \& Corlett, R.T. (2012) Asian tapirs are no elephants when it comes to seed dispersal. Biotropica, 44, 220-227.

Canale, G.R., Peres, C.A., Guidorizzi, C.E., Gatto, C.A.F. \& Kierulff, M.C.M. (2012) Pervasive defaunation of forest remnants in a tropical biodiversity hotspot. PLoS ONE, 7(8), e41671.

Cavanaugh, K.C., Gosnell, J.S., Davis, S.L., Ahumada, J., Boundja, P., Clark, D.B. et al. (2014) Carbon storage in tropical forests correlates with taxonomic diversity and functional dominance on a global scale. Global Ecology and Biogeography, 23 563-573.

Clements, T. (2010) Reduced expectations: the political and institutional challenges of REDD+. Oryx, 44, 309-310.

Elmqvist, T.M., Folke, C., Nyström, M., Peterson, G., Bengtsson, J., Walker, B. \& Norberg, J. (2003) Response 
diversity, ecosystem change, and resilience. Frontiers in Ecology and the Environment, 1, 488-494.

FaO (Food and Agriculture Organization of the UN) (2010) Global Forest Resources Assessment 2010. FAO, Rome, Italy.

Forget, P.M. \& JAnsen, P.A. (2007) Hunting increases dispersal limitation in the tree Carapa procera, a non-timber forest product. Conservation Biology, 21, 106-113.

Fragoso, J.M.V., Silvius, K.M. \& Correa, J.A. (2003) Long-distance seed dispersal by tapirs increases seed survival and aggregates tropical trees. Ecology, 84, 1998-2006.

GCP, IPAM, FFI, UNEP FI \& UNORCID (2014) Stimulating Interim Demand for REDD+ Emissions Reductions: The Need for a Strategic Intervention from 2015 to 2020. Global Canopy Programme, Oxford, UK, the Amazon Environmental Research Institute, Brasilia, Brazil; Fauna \& Flora International, Cambridge, UK; UN Environment Programme Finance Initiative, Geneva, Switzerland; UN Office for REDD+ Coordination in Indonesia, Indonesia.

HARRISON, R.D. (2011) Emptying the forest: hunting and the extirpation of wildlife from tropical nature reserves. BioScience, 919, 919-924.

Holbrook, K.M. \& Loiselle, B.A. (2009) Dispersal in a Neotropical tree, Virola flexuosa (Myristicaceae): does hunting of large vertebrates limit seed removal? Ecology, 90, 1449-1455.

Howe, H.F. \& Smallwood, J. (1982) Ecology of seed dispersal. Annual Review of Ecology and Systematics, 13, 201-228.

Jansen, P.A., Muller-Landau, H.C. \& Wright, S.J. (2010) Bushmeat hunting and climate: an indirect link. Science, 327, 30.

Kilgore, A., Lambert, T.D. \& Adler, G.H. (2010) Lianas influence fruit and seed use by rodents in a tropical forest. Tropical Ecology, 52, 265-271.

Kurten, E.L. (2013) Cascading effects of contemporaneous defaunation on tropical forest communities. Biological Conservation, 163, 22-32.

Maisels, F., Keming, E., Kemei, M. \& Toh, C. (2001) The extirpation of large mammals and implications for montane forest conservation: the case of the Kilum-ljim Forest, North-west Province, Cameroon. Oryx, 35, 322-331.

Miles, L., Dunning, E., Doswald, N. \& Osti, M. (2010) A Safer Bet for REDD+: Review of the Evidence on the Relationship between Biodiversity and the Resilience of Forest Carbon Stocks. UN-REDD Programme and UN Environment Programme-World Conservation Monitoring Centre. Http://www.unredd.net/index. php?option=com_docman\&task=doc_download $\&$ gid $=3272 \&$ Itemid $=53$ [accessed 22 July 2014].

Muller-Landau, H.C. (2007) Predicting the long-term effects of hunting on plant species composition and diversity in tropical forests. Biotropica, 39, 372-384.

Nuñez-Iturri, G. \& Howe, H.F. (2007) Bushmeat and the fate of trees with seeds dispersed by large primates in a lowland rain forest in western Amazonia. Biotropica, 39, 348-354.

Paoli, G.D., Wells, P.L., Meijaard, E., Struebig, M. J., Marshall, A.J., ObidZinski, K. et al. (2010) Biodiversity conservation in the REDD. Carbon Balance Management, 5, 1-9.

Parker, C., Mitchell, A., Trivedi, M., Mardas, N. \& Sosis, K. (2009) The Little REDD+ Book: An Updated Guide to Governmental and Non-governmental Proposals for Reducing Emissions from Deforestation and Degradation. Global Canopy Programme, Oxford, UK. Http://www.globalcanopy.org/materials/little-reddbook [accessed September 2012].

Peltzer, D.A., Allen, R.B., Lovett, G.M., Whitehead, D. \& WARDLE, D.A. (2010) Effects of biological invasions on forest carbon sequestration. Global Change Biology, 16, 732-746.
Peres, C.A. \& Palacios, E. (2007) Basin-wide effects of game harvest on vertebrate population densities in Amazonian forests: implications for animal-mediated seed dispersal. Biotropica, 39, 304-315.

Peters-Stanley, M., Gonzalez, G. \& Yin, D. (2013) Covering New Ground: State of the Forest Carbon Markets 2013. Forest Trends' Ecosystem Marketplace, Washington, DC, USA. Http://www.foresttrends.org/documents/files/SOFCM-full-report.pdf [accessed 9 July 2014].

Phelps, J., Webi, E.L. \& Adams, W. (2012) Biodiversity co-benefits of policies to reduce forest-carbon emissions. Nature Climate Change, 2, 497-503.

Phillips, O.L., Vásquez Martínez, R., Arroyo, L., Baker, T.R., KiLleEn, T., LeWIS, S.L. et al. (2002) Increasing dominance of large lianas in Amazonian forests. Nature, 418, 770-774.

Plan Vivo Foundation (2013) The Plan Vivo Standard for Community Payments for Ecosystem Services Programmes, Version: 2013. Plan Vivo Foundation, Edinburgh, UK.

Poulsen, J.R., Clark, C.J. \& Palmer, T.M. (2013) Ecological erosion of an Afrotropical forest and potential consequences for tree recruitment and forest biomass. Biological Conservation, 163, 122-130.

Redford, K. (1992) The empty forest. Bioscience, 42, 412-422.

Roubik, D.W. (1978) Competitive interactions between

Neotropical pollinators and Africanized honeybees. Science, 201, 1030-1032.

SASAKi, N. \& Putz, F.E. (2009) Critical need for new definitions of 'forest' and 'forest degradation' in global climate change agreements. Conservation Letters, 2, 226-232.

Scharlemann, J.P., Kapos, V., Campbell, A., Lysenko, I., Burgess, N.D., Hansen, M.C. et al. (2010) Securing tropical forest carbon: the contribution of protected areas to REDD. Oryx, $44,352-357$.

SCHnitzer, S.A. \& Bongers, F. (2011) Increasing liana abundance and biomass in tropical forests: emerging patterns and putative mechanisms. Ecology Letters, 14, 397-406.

Schoene, D., Killmann, W., von Lüpke, H. \& LoycheWilkie, M. (2007) Definitional Issues Related to Reducing Emissions from Deforestation in Developing Countries. Food and Agriculture Organization of the UN, Rome, Italy.

Strassburg, B.B.N., Kelly, A., Balmford, A., Davies, R.G., Gibis, H.K., Lovetт, A. et al. (2010) Global congruence of carbon storage and biodiversity in terrestrial ecosystems. Conservation Letters, 3, 98-105.

Terborgh, J., Nuñez-Iturri, G., Pitman, N.C., Valverde, F.H.C., Alvarez, P., Swamy, V. et al. (2008) Tree recruitment in an empty forest. Ecology, 89, 1757-1768.

Thompson, I., Mackey, B., McNulty, S. \& Mosseler, A. (2009) Forest Resilience, Biodiversity, and Climate Change. A Synthesis of the Biodiversity/Resilience/Stability Relationship in Forest Ecosystems. Technical Series no. 43. Secretariat of the Convention on Biological Diversity, Montreal, Canada.

UnfCCC (UN Framework Convention On Climate Change) (2008) Report of the Conference of the Parties on its Thirteenth Session, held in Bali from 3 to 15 December 2007. Addendum. Part Two: Action taken by the Conference of the Parties at its Thirteenth Session. March 2008. Http://unfccc.int/resource/docs/2007/cop13/ eng/06a01.pdf\#page=3 [accessed September 2012].

van der Heijden, G.M.F. \& Phillips, O.L. (2009) Liana infestation impacts tree growth in a lowland tropical moist forest.

Biogeosciences Discuss, 6, 3133-3158.

van der Werf, G.R., Morton, D.C., DeFries, R.S., Olivier, J.G., Kasibhatla, P.S., JaCKSON, R.B. et al. (2009) $\mathrm{CO}_{2}$ emissions from forest loss. Nature Geoscience, 2, 737-738. 
Vanthomme, H., Bellé, B. \& Forget, P.M. (2010) Bushmeat hunting alters recruitment of large-seeded plant species in Central Africa. Biotropica, 42, 67-679.

VCS \& CCB (Verified Carbon Standard \& The Climate, Community \& Biodiversity Alliance) (2013) Project Description Template, VCS Version 3, CCB Standards Second Edition. Washington, DC, USA.

Venter, O. \& КоH, L.P. (2012) Reducing emissions from deforestation and forest degradation (REDD+): game changer or just another quick fix? Annals of the New York Academy of Sciences, 1249, 137-150.

Vidal, M.M., Pires, M.M. \& Guimarães, P.R. Jr (2013) Large vertebrates as the missing components of seed-dispersal networks. Biological Conservation, 163, 42-44.

WANG, B.C., Sork, V.L., LeONG, M.T. \& SMITH, T.B. (2007) Hunting of mammals reduces seed removal and dispersal of the Afrotropical tree Antrocaryon klaineanum (Anacardiaceae). Biotropica, 39, 340-347.

Wilkie, D.S., Bennett, E.L., Peres, C.A. \& Cunningham, A.A. (2011) The empty forest revisited. Annals of the New York Academy of Sciences, 1223, 120-128.
Wright, S., Hernandez, A. \& Condit, R. (2007) The bushmeat harvest alters seedling banks by favoring lianas, large seeds, and seeds dispersed by bats, birds, and wind. Biotropica, $39,363-371$.

\section{Biographical sketches}

Amy Hinsley uses interdisciplinary methods to study the international wildlife trade. Before joining the Durrell Institute of Conservation and Ecology she was a member of the Science team at Fauna \& Flora International. A в I G A IL EN T W IS T LE has a background in bat ecology and has worked in international conservation for nearly 20 years. Her research interests include the use of flagship species and approaches to determining conservation impact. DOROTHEA PIO is involved in the development and implementation of several REDD+ projects in Indonesia. Before joining Fauna \& Flora International she worked for UNESCO supporting protected area management in Sumatra. She has a background in tropical forest ecology and conservation and has studied how extinctions induced by climate change may impact the tree of life in Southern Africa. 